ENGINEERING DRAWING AND DESIGN II 
Macmillan Technician Series

P. J. Avard and J. Cross, Workshop Processes and Materials I

G. D. Bishop, Electronics II

John Elliott, Building Science and Materials II/III

D. E. Hewitt, Engineering Science II

P. R. Lancaster and D. Mitchell, Mechanical Science III

R. Lewis, Physical Science I

Noel M. Morris, Electrical Principles II

Noel M. Morris, Electrical Principles III 


\title{
ENGINEERING DRAWING AND DESIGN II
}

\author{
Peter Astley
}

T. Eng. (CEI), M.I. Plant E., M.I.E.D.

Foley College of Further Education, Stourbridge 
All rights reserved. No part of this publication may be reproduced or transmitted, in any form or by any means, without permission.

First published 1978 by

THE MACMILLAN PRESS LTD

London and Basingstoke

Associated companies in Delhi Dublin

Hong Kong Johannesburg Lagos Melbourne

New York Singapore and Tokyo

\section{British Library Cataloguing in Publication Data}

Astley, Peter George Warren

Engineering drawing and design II. - Macmillan technician series).
1. Engineering drawing
2. Mechanical drawing

I. Title II. Series

$604^{\prime} .2^{\prime} 4$

T353

ISBN 978-0-333-21703-0 ISBN 978-1-349-03314-0 (eBook)

DOI 10.1007/978-1-349-03314-0

This book is sold subject to the standard conditions of the Net Book Agreement.

The paperback edition of this book is sold subject to the condition that it shall not, by way of trade or otherwise, be lent, resold, hired out, or otherwise circulated without the publisher's prior consent in any form of binding or cover other than that in which it is published and without a similar condition including this condition being imposed on the subsequent purchaser. 
Good design is usually achieved when persons with suitable education and training can collect and simplify information relevant to a requirement; make the information manageable within the available resources of materials and techniques, and ultimately user satisfaction will be obtained. 


\section{Contents}

Foreword

Preface

1. Engineering Communication

The Engineering Drawing

Conventional Representation of Standard Parts

Weld Symbols

Some General Principles

Photography as a Means of Engineering

Communication

The Model as a Means of Engineering

Communication

2. The Engineering Designer

Prelude to Design

Designers and Safety

3. Design Elements and Logic

Safety

A Working Plan

4. The Specification

The Feasibility Study

5. Joining of Materials

Bolts, Screws and Nuts

Riveted Joints

Welded Joints

Adhesives
32

35

40

42

42

42

45

49

50

50

60

66

72
6. The Product and Factors Affecting Product Appearance

Appendix A: Some Relevant British Standards

Appendix B: The Forming of Metals; Properties and Uses

Appendix C: Preferred Metric Basic Sizes; Preferred Numbers 94

Appendix D: Conversion Tables

Assignments

Questions 


\section{Foreword}

This book is written for one of the many technician courses now being run at technical colleges in accordance with the requirements of the Technician Education Council (TEC). This Council was established in March 1973 as a result of the recommendation of the Government's Haslegrave Committee on Technical Courses and Examinations, which reported in 1969. TEC's functions were to rationalise existing technician courses, including the City and Guilds of London Institute (C.G.L.I.) Technician courses and the Ordinary and Higher National Certificate courses (O.N.C. and H.N.C.), and provide a system of technical education which satisfied the requirements of 'industry' and 'students' but which could be operated economically and efficiently.

Four qualifications are awarded by TEC, namely the Certificate, Higher Certificate, Diploma and Higher Diploma. The Certificate award is comparable with the O.N.C. or with the third year of the C.G.L.I. Technician course, whereas the Higher Certificate is comparable with the H.N.C. or the C.G.L.I. Part III Certificate. The Diploma is comparable with the O.N.D. in Engineering or Technology, the Higher Diploma with the H.N.D. Students study on a part-time or block-release basis for the Certificate and Higher Certificate, whereas the Diploma courses are intended for full-time study. Evening study is possible but not recommended by TEC. The Certificate course consists of fifteen Units and is intended to be studied over a period of three years by students, mainly straight from school, who have three or more C.S.E. Grade III passes or equivalent in appropriate subjects such as mathematics, English and science. The Higher Certificate course consists of a further ten Units, for two years of part-time study, the total time allocation being 900 hours of study for the Certificate and 600 hours for the Higher Certificate. The Diploma requires about 2000 hours of study over two years, the Higher Diploma a further 1500 hours of study for a further two years.

Each student is entered on to a Programme of study on entry to the course; this programme leads to the award of a Technician Certificate, the title of which reflects the area of engineering or science chosen by the student, such as the Telecommunications Certificate or the Mechanical Engineering Certificate. TEC have created three main Sectors of responsibility 
Sector A responsible for General, Electrical and Mechanical Engineering

Sector B responsible for Building, Mining and Construction Engineering

Sector C responsible for the Sciences, Agriculture, Catering, Graphics and Textiles.

Each Sector is divided into Programme committees, which are responsible for the specialist subjects or programmes, such as A1 for General Engineering, A2 for Electronics and Telecommunications Engineering, A3 for Electrical Engineering, etc. Colleges have considerable control over the content of their intended programmes, since they can choose the Units for their programmes to suit the requirements of local industry, college resources or student needs. These Units can be written entirely by the college, thereafter called a college-devised Unit, or can be supplied as a Standard Unit by one of the Programme committees of TEC. Assessment of every Unit is carried out by the college and a pass in one Unit depends on the attainment gained by the student in his coursework, laboratory work and an end-of-Unit test. TEC moderate college assessment plans and their validation; external assessment by TEC will be introduced at a later stage.

The three-year Certificate course consists of fifteen Units at three Levels: I, II and III, with five Units normally studied per year. A typical programme might be as follows.

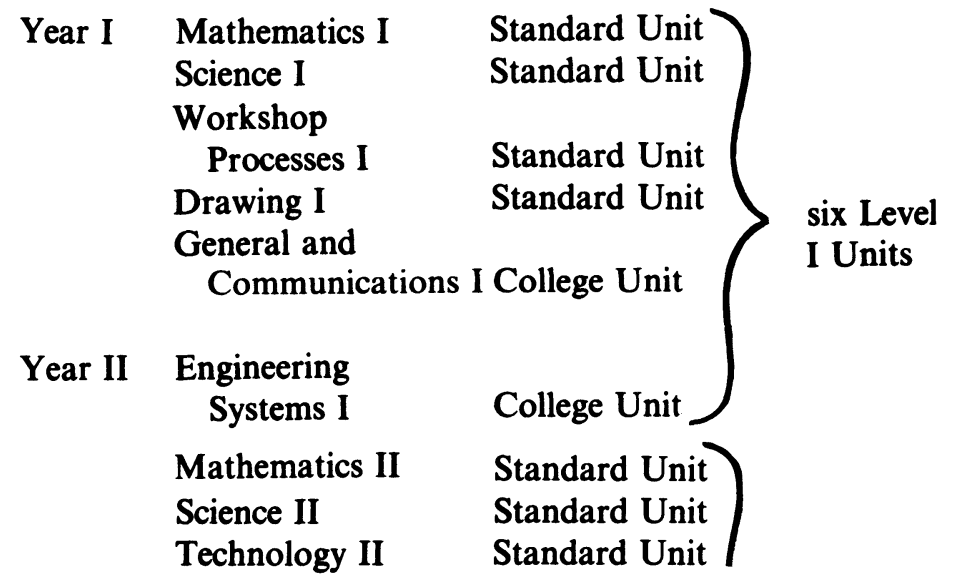

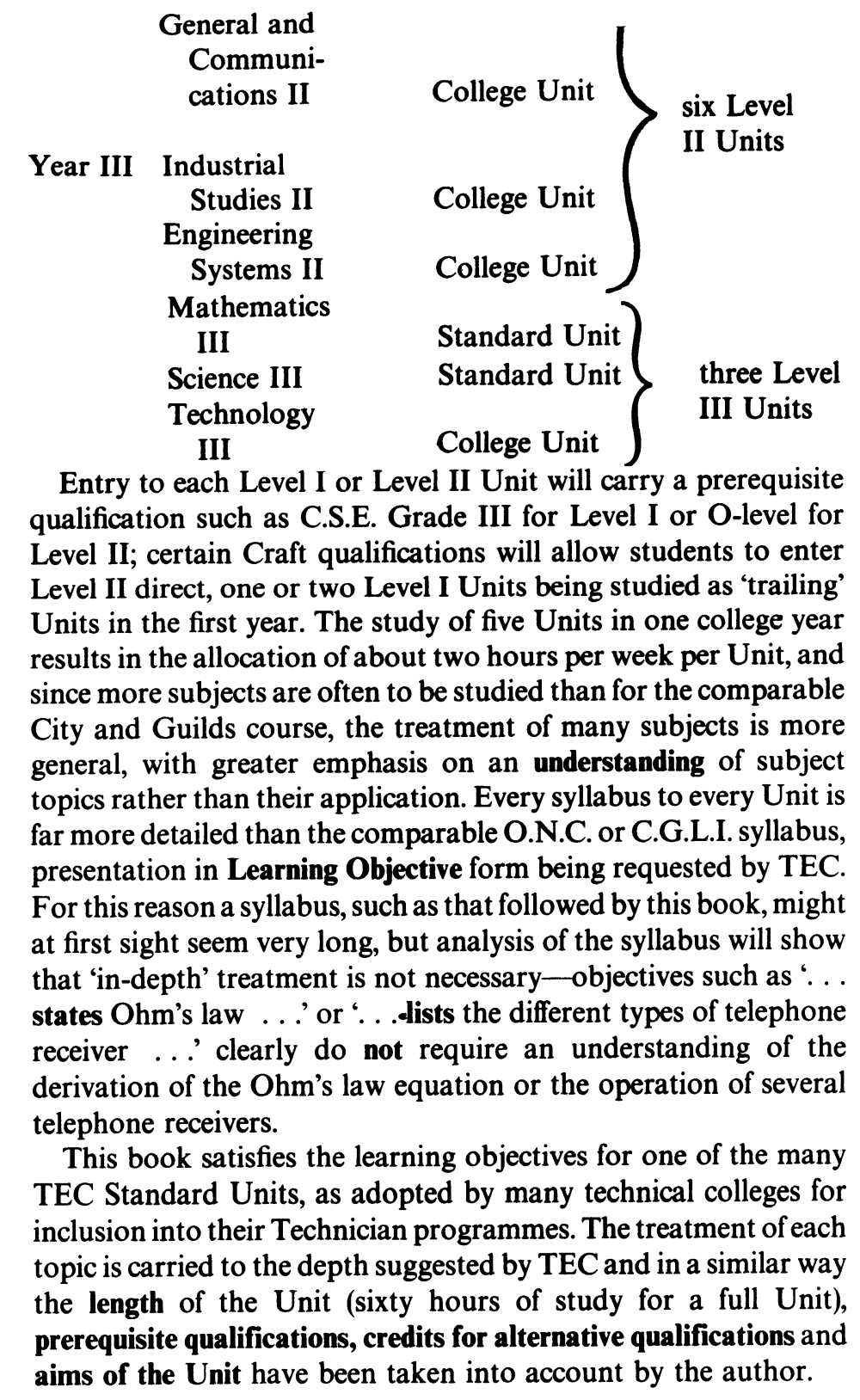
Communi-

Studieering

Systems II

Mathematics

$$
\text { III }
$$

Science III

Technology qualification such as C.S.E. Grade III for Level I or O-level for results in the allocation of about two hours per week per Unit, and since more subjects are often to be studied than for the comparable City and Guilds course, the treatment of many subjects is more general, with greater emphasis on an understanding of subject topics rather than their application. Every syllabus to every Unit is far more detailed than the comparable O.N.C. or C.G.L.I. syllabus, presentation in Learning Objective form being requested by TEC. For this reason a syllabus, such as that followed by this book, might at first sight seem very long, but analysis of the syllabus will show that 'in-depth' treatment is not necessary-objectives such as '. . states Ohm's law ...' or ' . . .dists the different types of telephone derivation of the Ohm's law equation or the operation of several elephone receivers.

This book satisfies the learnin TEC Standard Units, as adopted by many technical colleges fo the length of the Unit (sixty hours of study for a full Unit) aims of the Unit have been taken into account by the author. 


\section{Preface}

This book has been written to satisfy the aims and Unit topic areas of the Technician Education Council Standard Unit, Engineering Drawing and Design II, Unit Level II. It is assumed that the student will already possess a pass grade at G.C.E. O-level or a C.S.E. Grade $I$ in engineering or technical drawing; therefore a thorough coverage of basic draughting techniques has not been attempted.

Having trodden the path from junior draughtsman to chief draughtsman, I sincerely hope that this publication will help to encourage students to further their studies. Design can mean different things to different people, but the content of this TEC Unit affords the opportunity for lecturers to provide a real-world approach to the subject.

For checking the script, my thanks go to Mr R. F. Hall, M.I.E.D. I am also grateful to various companies for permission to use photographs; their names appear within the appropriate sections of the book.

Finally, I should like to thank my wife, Sheila, for her steadfast work in preparing the script for publication and for showing her usual patience.

Finchfield, 1977

Peter Astley 